\title{
Oyster Mushroom Production in Meghalaya: A Potential Venture
}

\section{Lakshmi Dhar Hatai}

Department of Social Science, College of Horticulture \& Forestry, Central Agricultural University, Pasighat, Arunachal Pradesh, India Corresponding author: lakshmidharhatai@gmail.com (ORCID ID: 0000-0001-9313-9797)

Received: $17-07-2021$

Revised: 24-10-2021

Accepted: 29-11-2021

\begin{abstract}
Oyster mushroom production, which is profitable agri-business enterprise for enhancing farm income, generating additional employment and subsistence to nutritional security. Considering the growing demand and importance of oyster mushroom production for promising enterprise, an attempt has been made to estimate the cost and returns of growing oyster mushroom, to identify various determinants affecting its value of mushroom productivity. The study was carried out in Rongram block, West Garo Hills of Meghalaya using 60 oyster mushroom growers. Findings revealed that the total cost depicted a decreasing trend with increase in the size of beds spawned due to economies of scale. On overall basis, the total cost estimated to be ₹ 467 per 5 units of polybag beds spawned. The returns from mushroom cultivation depicted a positive association with farm size; these are ₹ 58/kg, ₹ 76/kg and ₹ 120/kg for small, medium and large mushroom farms respectively. It was worked out in the overall farm size that one rupee invested in mushroom growing, yields about ₹ 1.55 . The input-output ratio was highest on large mushroom farms (1.82), followed by medium (1.48) and small (1.35) farms. The single window input delivery system should be encouraged in the study area. There was a felt need for a linkage and full co-operation between the state government, financial institutions, researchers, scientists, extension workers and mushroom growers on different advanced technological aspects of better production oyster mushroom, which would help the farmers' to get remunerative prices for their products.
\end{abstract}

\section{HIGHLIGHTS}

(0 Oyster mushroom production is one of the potential agri-business enterprise for enhancing farm income and nutritional security in the Garo Hills region of Meghalaya.

( Mushroom growers of larger farm size appear to using the resources more efficiently as compared to smaller farms.

Keywords: Mushroom, Input Output Ratio, Value addition, Meghalaya

Mushroom farming today is being practiced in more than 100 countries and its production is increasing at an annual rate of 6-7 per cent (Boruah et al. 2021). It is very much advantageous as because it can be grown even by landless farmers, that too on waste material and could be a good source of protein (Ambili and Nitiya, 2014). Oyster mushroom (Pleurotus spp.), commonly known as "Dhingri" in India. The mushroom crop is widely grown all over India and had a production of 76 thousand tonnes for the year 2015-16 (GoI, 2016). It is popularly grown in the states of Orissa, Karnataka, Maharashtra,
Andhra Pradesh, Madhya Pradesh, Himachal Pradesh, West Bengal and in the North-Eastern States of Meghalaya, Tripura Manipur, Mizoram and Assam (Directorate of Mushroom Research (ICAR) Solan, 2011). Meghalaya produces about 27 metric tonnes of mushroom per annum (Government of Meghalaya, 2018). To raise income, employment,

How to cite this article: Hatai, L.D. (2021). Oyster Mushroom Production in Meghalaya- A Potential Venture. Economic Affairs, 66(04): 577-582.

Source of Support: None; Conflict of Interest: None (a) (8) 
profitability, food security, global competitiveness and social welfare, a holistic approach with emphasis in mushroom production has become imminent. Farmers' income can be increased not just by increasing production but also through value addition. Adoption of modern technology and sustainable utilization of resources and farm inputs can help mushroom growers in minimizing the cost of production. Mushroom enterprise plays predominant role towards employment generation, food and nutritional security and enhancing income. Several small and medium and large companies have taken up mushroom growing on industrial scale to supply good quality of fresh, dried and canned mushroom to the domestic and international markets (Thakare and Gupta, 2014). Mushroom production is a viable, technically feasible and profitable venture. Since mushroom cultivation is capital-intensive and the financial assistance through institutional agencies at cheaper interest rate would help increase mushroom production (Singh et al. 2010).

Taking into consideration the growing demand and importance of oyster mushroom production for promising enterprise, the present study was undertaken with the following specific objectives:

1. To estimate cost and returns of growing oyster mushroom in different farm-size categories,

2. To identify various determinants affecting its value of mushroom productivity.

\section{Methodology}

To estimate the costs and returns from mushroomgrowing and explore the factors affecting its value productivity, a field survey was conducted. Rongram CD Block of West Garo Hills district was selected purposively, which has the highest concentration of mushroom growers and randomly sample of 60 mushroom farmers were selected for the study. To collect the necessary information to satisfy the objectives of the study, survey was conducted during 2017-18. The selected respondents were classified into three categories on the basis of their number of polybag beds spawned using cumulative cube root frequency method. Thus, there were $30(50 \%)$ small, $20(33.33 \%)$ medium and 10 $(16.67 \%)$ large mushroom growers in the sample categories (table 1).
Table 1: Categories of Oyster mushroom growers according to number of polybag beds spawned

\begin{tabular}{llll}
\hline & $\begin{array}{l}\text { Size : No. } \\
\text { of poly } \\
\text { bags bed } \\
\text { (poly bag } \\
\text { bed Size }= \\
\text { Categories of } \times \text { Oyster } \\
\text { mushroom farm } \\
\text { cm) }\end{array}$ & $\begin{array}{l}\text { Average } \\
\text { growers } \\
\text { (No.) }\end{array}$ & $\begin{array}{l}\text { farm size } \\
\text { (units of } \\
\text { polybag } \\
\text { beds) }\end{array}$ \\
\hline $\begin{array}{l}\text { Small } \\
\text { Mushroom farm }\end{array}$ & $<100$ & $30(50)$ & 64 \\
$\begin{array}{l}\text { Medium } \\
\text { Mushroom farm }\end{array}$ & $100-200$ & $20(33.33)$ & 162 \\
$\begin{array}{l}\text { Large } \\
\text { Mushroom farm }\end{array}$ & $>200$ & $10(16.67)$ & 315 \\
Total & - & $60(100)$ & 180 \\
\hline
\end{tabular}

Figure in parenthesis indicate percent of mushroom grower to total growers.

\section{Analytical tools}

In the present study, Cobb-Douglas function was specified the logarithmic form of which is given in equation (1):

$$
\begin{gathered}
\log Y=\log A+b_{1} \log X_{1}+b_{2} \log X_{2}+\ldots \ldots \ldots \ldots \ldots \ldots+ \\
b_{5} \log X_{5}+b_{6} \log X_{6}+u
\end{gathered}
$$

where, $Y$ represents the value productivity per polybag bed unit spawned. Xi's, the selected explanatory variables (Rupees per 5 units of polybag beds); A, the technical efficiency parameter and bi the elasticity of production of the respective variable at the mean level of input use and output. The ' $u$ ' denotes error term (Singh, R. and Singh J.M. 2018).

Various explanatory and explained variables included in the analysis were as follows:

$Y=$ Gross returns from mushroom growing $(₹ / 5$ unit beds)

$X_{1}=$ Cost of Paddy straw ( $₹ / 5$-units)

$X_{2}=$ Cost of spawn used ( $₹ / 5$-units)

$X_{3}=$ Cost of plant protection chemicals ( $₹ / 5$-units)

$X_{4}=$ Cost of labour for composting ( $₹ / 5$-Units)

$X_{5}=$ Cost of labour for filling and spawning (₹/5-units)

$X_{6}=$ Cost of labour for picking and packing (₹/5-units) 


\section{RESULTS AND DISCUSSION}

\section{Cost of Oyster mushroom growing on sample farm}

A perusal of Table 2 revealed that the total cost shows a decreasing trend with increase in the size of beds spawned due to economies of scale. The scale of economies is apparent for both fixed and operational costs. From the findings of the study on overall farms, the total cost estimated to be ₹ 467 per 5 units of polybag beds spawned and the operational cost account for $83.94 \%$ and fixed cost $16.05 \%$ of the total cost. In total cost, the expenditure on labour is the most important component accounting for $(26.76 \%)$ followed by cost on spawn (25.26\%). In fact, this basic input of labour explains the positive association with value productivity per bed spawned. By the different categories of farm size, the total cost per 5-units of beds is estimated to be ₹ 518 on small, ₹ 483 on medium and ₹ 420 on large mushroom farms with a major share of nearly 83 of the operational costs.

\section{Gross returns and net returns from Oyster mushroom production}

The estimated gross and net returns of oyster mushroom production of the sample farms were presented in Table 3. Results indicate that the oyster mushroom growing is profitable, where in overall farms, the estimated net return was estimated ₹ 683 per 5 units of polybeds. Both the returns over variable cost as well as net returns from mushroom cultivation are directly related to the farm size. It also reveals that the cost of mushroom production decreases with increase in farm size. Thus, larger farmers appear to using the resources more efficiently as compared to smaller farms. The returns from mushroom cultivation depicted a positive association with farm size; these are ₹ 58/ $\mathrm{kg}$, ₹ 76/kg and ₹ $120 / \mathrm{kg}$ for small, medium and large mushroom farms, respectively. It is worked out in the overall farm size that one rupee invested in mushroom growing, yields about ₹ 1.55. The input-output ratio is the highest on large mushroom farms (1.82), followed by medium (1.48) and small (1.35) farms.

\section{Determinants of value productivity of Oyster mushrooms}

The results of Cobb-Douglas regression analysis for determinants of value productivity on small, medium, large and overall mushroom farms are presented in Table 4.

\section{Small oyster mushroom farms}

On small mushroom farms, the coefficient of expenditure on plant protection chemicals is positive and significant at five per cent level of significance

Table 2: Cost of Oyster mushroom growing on sample farm (₹ per 5 units of polybag beds)

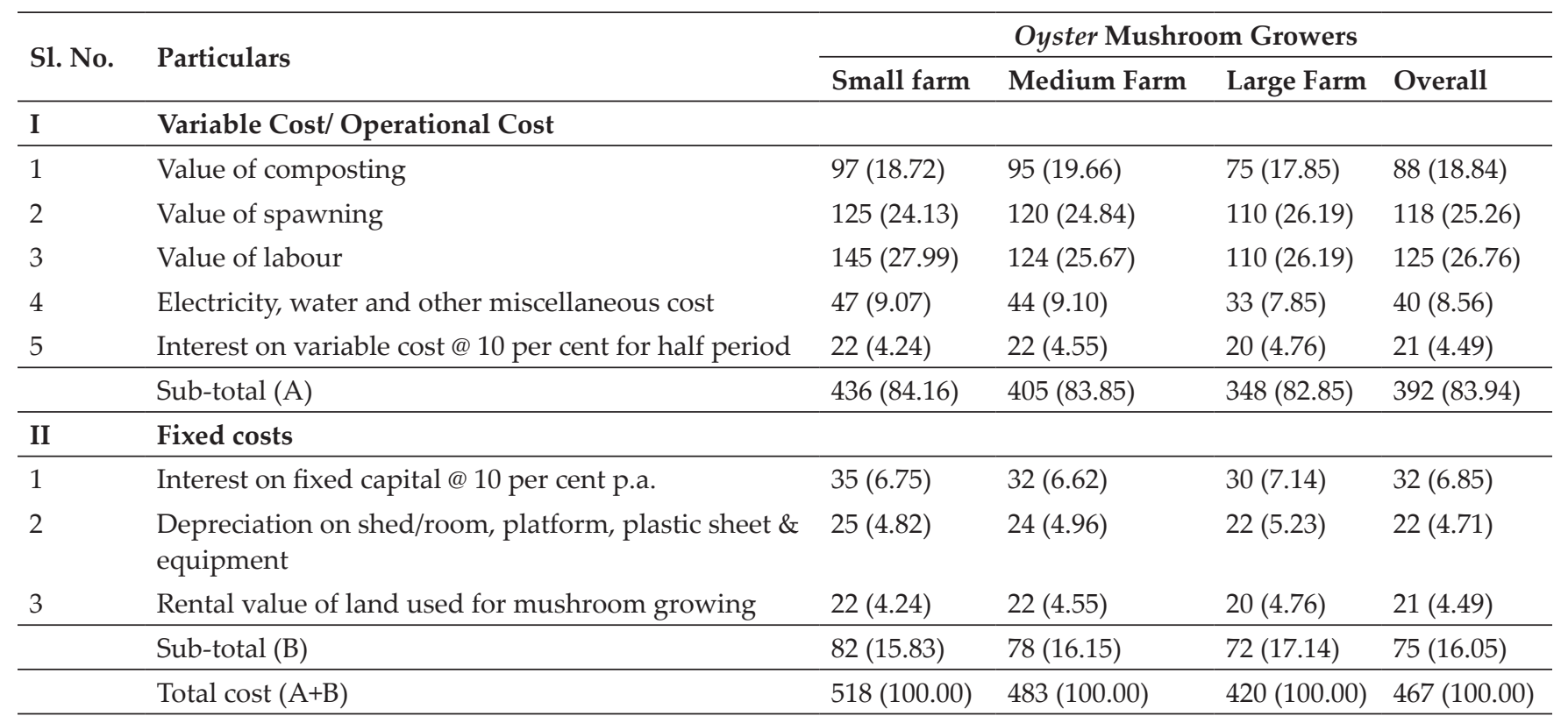

Note: Figures within the parenthesis indicate percentages of the total. 
Table 3: Economic analysis of Oyster mushroom production on sample farms

\begin{tabular}{llllll}
\hline \multirow{2}{*}{ S1 No. } & \multirow{2}{*}{ Particulars } & \multicolumn{3}{c}{ Oyster Mushroom Growers } \\
\cline { 3 - 5 } & & Small farm & Medium Farm & Large Farm & Overall \\
\hline 1 & Oyster mushroom yield (kg/5 units) & 5.12 & 4.98 & 5.02 & 5.05 \\
2 & Average price of mushroom (₹/kg) & 225 & 232 & 228 & 228 \\
3 & Gross returns from mushroom (₹/5 units) & 1152 & 1155 & 1144 & 1150 \\
4 & Variable cost (₹/5-units.) & 436 & 405 & 348 & 392 \\
5 & Fixed cost (₹/sq. m.) & 82 & 78 & 72 & 75 \\
6 & Total cost (₹/5-units & 518 & 483 & 420 & 467 \\
7 & Net returns (₹/5-units.) & 634 & 672 & 724 & 683 \\
8 & Returns to fixed farm resources (₹/5-units) & 716 & 750 & 796 & 758 \\
9 & Cost of production (₹/kg) & 165 & 158 & 145 & 155 \\
10 & Variable cost (₹/kg) & 114 & 102 & 98 & 104 \\
11 & Returns per kg (₹/kg) & 58 & 76 & 120 & 85 \\
12 & Input-output ratio & 1.35 & 1.48 & 1.82 & 1.55 \\
\hline
\end{tabular}

Table 4: Regression coefficient of Cobb-Douglas production function for Mushroom Farms in West Garo Hills of Meghalaya

\begin{tabular}{lllll}
\hline \multirow{2}{*}{ Particulars } & \multicolumn{4}{c}{ Regression Coefficient } \\
\cline { 2 - 5 } & Small farm & Medium Farm & Large Farm & Overall \\
\hline Intercept & 5.144 & 3.026 & 2.785 & 6.164 \\
Paddy straw $(₹)$ & $0.192(0.171)$ & $-0.187(0.158)$ & $0.574(0.273)$ & $0.035(0.872)$ \\
Spawn $(₹)$ & $-0.061(0.102)$ & $0.202^{* *}(0.113)$ & $0.225(0.142)$ & $0.012(0.066)$ \\
Plant protection chemicals $(₹)$ & $0.125^{* *}(0.51)$ & $0.048^{* *}(0.097)$ & $0.287^{* *}(0.136)$ & $0.194^{*}(0.038)$ \\
Labour for composting (₹) & $0.160^{* *}(0.081)$ & $-0.062(0.092)$ & $0.560^{* *}(0.197)$ & $0.068(0.052)$ \\
Labour for filling and spawning operation $(₹)$ & $-0.087(0.042)$ & $0.045(0.124)$ & $0.366(0.265)$ & $-0.056(0.042)$ \\
Labour for picking and packing & $0.146^{* *}(0.079)$ & $0.354^{* *}(0.178)$ & $0.132(0.081)$ & $0.178^{*}(0.047)$ \\
Coefficient of multiple determinations $\left(R^{2}\right)$ & 0.97 & 0.88 & 0.97 & 0.97 \\
Adjusted coefficient of multiple determinations $\left(R^{2}\right)$ & 0.94 & 0.86 & 0.95 & 0.95 \\
\hline
\end{tabular}

Figures in parentheses indicate standard errors of regression coefficients; **5 per cent level of significance.

showing thereby that with increase in expenses on plant protection chemical-use by one per cent, the resultant value productivity of mushroom would increase by 0.12 percent. The regression coefficient of expenses on labour for composting is also be positive and significant at five per cent level of significance which reveals that with one per cent increase in expenditure on this variable, the value productivity of mushroom would increase by 0.16 percent. Similarly, the regression coefficient for expenditure on labour use for picking and packing operation is also found to be positive and significant at five per cent level of significance revealing that with increase in expenditure on labour for picking and packing by one per cent, the value productivity of mushroom would increase by 0.14 percent.
The regression coefficient of spawn is found to be negative in-case of small size of mushroom growers. It is also observed that the regression coefficients of other explanatory variables are insignificant. It reveals that the value of adjusted coefficient of multiple determination $\left(\mathrm{R}^{2}\right)$ is very high explaining $94 \%$ of the variations in mushroom productivity by the explanatory variables included in the regression analysis.

\section{Medium oyster mushroom farms}

In Table 4, The coefficient of expenditure on plant protection chemicals is found positive and significant at five per cent of significance level which shows that with one per cent increase in the value of the variable, the resultant value productivity of 
mushroom would increase by 0.048 percent. The coefficients of labour use for picking and packing operation and spawn used are found to be positive and significant at five per cent level of significance. Thus, with increase in expenses on labour for picking and packing by one per cent the value productivity of mushroom would increase by 0.35 percent. Similarly, spawn shows with one percent increase in value, the resultant value productivity of mushroom would increase by 0.20 percent. The regression coefficients of expenses on paddy straw, labour for composting were negative, showing their over-use on medium farms but these were non-significant variables. For medium mushroom farms, the value of adjusted coefficient of multiple determination $\left(R^{2}\right)$ suggest that 86 per cent of the variations in the value productivity of mushroom could be explained by the independent variables included in regression model.

\section{Large oyster mushroom farms}

From the Table 4, the coefficient of expenditure on plant protection chemicals is positive and significant at five per cent of significance level which shows that with one per cent increase in the value of this variable, the resultant value productivity of mushroom would increase by 0.28 percent. The coefficient of labour for composting is also found to be significant at $5 \%$ level of significance, thereby showing increase in productivity by 0.56 percent with unit per cent rise in expenses on labour for composting operation. The regression coefficients of paddy straw, spawn, labour for filling and spawning operation, and labour for picking and packing operations are positive but non-significant. It was observed that on large farms, the explanatory variables could explain 95 percent of the variations in productivity of mushroom.

\section{Overall oyster mushroom farm}

On overall oyster mushroom farm basis, the coefficients of expenditure on plant protection chemicals and labour for picking and packing operations are positive and significant at one per cent level of significance showing that with increase in expenditure on these variables by one per cent, the resultant value productivity of mushroom would increase by 0.19 percent and 0.17 percent respectively. The coefficients of expenses incurred on paddy straw, spawn and labour for composting are positive, but non-significant. It shows that efficient use of plant protection chemicals and labour can further enhance the value productivity of mushroom in a significant way. The regression coefficient of other explanatory variables such as expenses on labour for filling and spawning operation was found negative, but non-significant. The study revealed that 95 percent of the variations in productivity of mushroom could be explained by the independent variables included in the regression model.

\section{CONCLUSION}

On the basis of the above findings and discussions of the study, the following can be suggested for multiple benefits, making a win-win proposition as a promising mushroom enterprise. It was observed that increase in farm size is accompanied by higher productivity and remunerative price fetched by large farmers as compared to other categories of mushroom growers. The highest input-output ratio (1.82) was achieved by the large farms because of judicious expenditure in mushroom production and obtaining a sizeable amount of returns. It is revealed that mushroom growing is a labour intensive enterprise and it is the most important constituent of the variable cost, followed by expenses on composting and spawning. The net returns have been found higher on large mushroom farms (₹ 724), followed by medium (₹ 672) and small farms (₹ 634).

- Efforts should be made towards appraising the mushroom growers of appropriate techniques and application of modern inputs for better production of oyster mushroom.

- Input delivery system should be based on the single window approach which encourages in the study area for timely, easy and convenient availability of inputs to mushroom growers.

- It is necessary for better marketing and value addition of mushroom, so that farmers can get remunerative price for their product.

- Mushroom farmers should be educated about the farm-size economies of mushroom production. Mushroom growers should be provided training on proper disinfection of pucca sheds and preparation of good quality compost. 
- There is the need to disseminate the nutritive value of mushroom to increase its consumption and thereby production in the study area.

- There is a felt need for a linkage and full co-operation between the state government, financial institutions, researchers, scientists, extension workers and mushroom growers on different advanced technological aspects of better production oyster mushroom, effective marketing which help the farmers to get remunerative prices from this enterprise.

\section{ACKNOWLEDGEMENTS}

The improvements suggested by the anonymous referees and editors that helped me to improve the contents and quality of this paper are gratefully acknowledged.

\section{REFERENCES}

Ambili, S. and Nithya, T.P. 2014. Oyster mushroom cultivationA study in Palakkad district, Kerela. Int. J. Management. Soc. Sci. Res. Rev., 1: 104-105.
Directorate of Mushroom Research (ICAR), Solan (India). 2011. Mushrooms cultivation, marketing and consumption. Directorate of Mushroom Research (Indian Council of Agricultural Research).

GoI (Government of India) 2016. Agricultural Statistics at a Glance. Ministry of Agriculture and Farmers Welfare, New Delhi.

Government of Meghalaya. 2018. Directorate of Agriculture, Shillong, Meghalaya. http://www.megagriculture.gov.in/ PUBLIC/dwd_docs/MissionMushroom.pdf

Ram, S., Bishnoi, D.K. and Singh, A. 2010. Cost Benefit Analysis and Marketing of Mushroom in Haryana, Agric. Eco. Res. Rev., 23: 165-171.

Sarodee Boruah, Sanjoy Borthakur and Neog, M. 2021. Oyster Mushroom Cultivation - A Budding Enterprise for Self-Employment of Rural Youth and Farm Women in Tinsukia District of Assam. Int. J. Curr. Microbiol. App. Sci., 10(01): 2155-2161.

Singh, R. and Singh, J.M. 2018. Mushroom growing in Punjab: cost components and determinants affecting its productivity, Agric. Eco. Res. Rev., 31(2): 299-304. 